DOI: https://doi.org/10.47405/mjssh.v6i1.607

\begin{tabular}{|c|c|}
\hline$x=$ & Malaysian Journal of Social Sciences and Humanities (MJSSH) \\
\hline Malaysian Journal of & Volume 6, Issue 1, January 2021 \\
\hline (MJ-ssH) & e-ISSN : 2504-8562 \\
\hline & $\begin{array}{l}\text { Journal home page: } \\
\text { www.msocialsciences.com }\end{array}$ \\
\hline
\end{tabular}

\title{
Financial Planning Towards Marriage Among the Millennial Generation
}

\author{
Nur Muzdalifah Zulkarnain11, Zaimah Ramli1 \\ 1Universiti Kebangsaan Malaysia (UKM)
}

Correspondence: Zaimah Ramli (zaimahr@ukm.edu.my)

\begin{abstract}
The economic situation that is getting more challenging, and the desire to dream for a luxurious marriage is a challenge faced by couples who are heading towards marriage nowadays. Thus, the objective of this study is to identify whether the millennial generation has a specific saving for marriage or not, identifying items and expenditure estimates for their wedding, and identifying the millennial generation's financial sources to celebrate their wedding. The purposive sampling technique was used in this study. The data collection instrument was using questionnaires. Questionnaires were distributed at Medan MARA Marriage Course, Kuala Lumpur. As many as 85 people of the millennial generation (aged 18 to 40 years old) who are Muslims and have not been married were involved in this study. Descriptive statistics were used to answer the study objective. Study results found that most of the millennial generation has a specific saving to get married, especially men. The estimated value for wedding expenses is between RM10,000 to RM15,999. Savings, loans, and family contributions were three main financial sources for the millennial generation to accomplish their wedding. The study implication suggests that the millennial generation be wiser in personal financial planning, especially in planning savings and expenses for their wedding.
\end{abstract}

Keywords: financial planning, expenditure, marriage, savings, millennial generation

\section{Introduction}

Finance is really important in life and every individual must be responsible for planning their finances. Financial management involves financial planning that is related to acquisitions, allocations, and financial sources control that are the worries of an individual (Nor Syahidah \& Norasmah, 2017). Ineffective financial planning will cause a financial crisis to happen (Willis, 2008). Financial matters not only give financial satisfaction but also marriage satisfaction and life quality (Copur \& Eker, 2014). Financial difficulties and dissatisfaction with a person's financial status can cause marriage conflicts and divorce. According to Copur and Eker (2014), financial issues are the cause of similar misunderstandings in personal, marriage, and family relationships. Most married couples are not worried about how much money they have but have more to say about the dissatisfaction with the money spent by them. Therefore, shortcomings like this are related a lot to the cause of a divorce happening.

In facing the wave of modernisation and a more challenging economic situation, the desire to dream for a luxurious marriage becomes a challenge for couples who want to get married. Weddings beyond financial capabilities have become the norm in Malaysian society nowadays, especially in Kuala Lumpur. Rumaya et al. (2014) found that 37 percent of individuals who are married for just two years 
have already expressed dissatisfaction with their marriage because of financial problems. Rumaya et al. (2014) also found that many husbands and wives nowadays fail to make long term financial planning and take the easy step of borrowing money to get married.

Malaysian Department of Insolvency (2020) report found that the number of bankruptcy cases for the period of 2015 to December 2019 was as many as 84,805 people. 21,844 people are from the age of 18 to 34 years old who are categorised as the millennials. These bankruptcies happened because of personal loans, vehicle hire purchases, housing loans, business loans, credit card debts, social guarantors, other indebtednesses, corporate loans, income tax debts and study loans. Consumer patterns and easy access to personal loan facilities cause millennials to end up with bankruptcy because they lose control over their finances (Chen-Chen at al., 2018). More than $80 \%$ of them want to acquire money to enjoy life experiences and own anything that they want with the money.

The Malaysian Millenial Generation is the biggest segment of the national population that represents the largest consumer segment and will dominate the national labour force after retirements from the Boomers Generation. They live ambitiously and money-oriented (Koon \& Nurazrin, 2015) and financial issues will become a responsibility that needs to be borne by everyone. This responsibility will add up when the millennials get married (Liezel \& Chrizaan, 2015). Although there are studies on marriage financial planning found before this, studies like that among the millennial generation are not found. Many past researchers touch on the financial planning aspect after retirement, workers and students' financial planning. Thus, the objective of this study is to identify whether the millennial generation has a specific saving towards marriage or not, identifying items and expenses for their wedding and identifying the financial sources for the millennial to celebrate their wedding.

\section{Literature Review}

The literature review in this study will explain the concepts of the millennial generation, financial management, financial planning, marriage expenditure and financial sources.

\section{The millennialgeneration}

The millennial generation is the generation that was born during the internet booming era where their daily activities used a lot of simple and easy communication technologies like email, SMS, instant messaging and social medial like Facebook and Twitter (Dwiyun et al., 2017). The millennial generation is a generation that was born in the early 1980s to the 2000s (Stanimir, 2015). Following that birth year approximate, millennials are 20 to 40 years old this year. The millennial generation does not know the world without email, mobile phones, smartphones, laptops, digital cameras, and social media platforms (Markus, 2017; Dwiyun et al., 2017). According to Syahira et al. (2013), these new technologies influence the lifestyle of their generation.

\section{Financialmanagement}

According to Normaizatul et al. (2016), financial management can be defined as a set of behaviours in cash and credit management, financial planning, insurance, retirement, investment and asset planning. Besides, personal financial management helps individuals to manage finances including budgets, savings, investments, debt management and other aspects related to personal money where an individual can achieve personal goals (Thulasimani, 2015). In other words, financial management is an income control and expenditure arrangement process through financial planning. According to Noraihan et al. (2013), good financial management involves financial planning that can help to identify ways to prepare budgets, spending particular money and having savings.

\section{Financialplanning}

Financial planning is a prediction, collection, withdrawal, investing and cash planning process that is needed by an individual to operate smoothly (Irawan et al., 2018). Garman and Forgue (2006) define 
financial planning as a process to develop and execute a financial plan that is coordinated to achieve financial success. Financial planning is also referred to as the basis for future income estimations, expenditures, and related issues (Md Abdul Jalil et al., 2013). According to Kapoor et al. (2012), personal financial planning is a process of individual financial management to achieve personal economic satisfaction. This process allows an individual to control financial conditions. Besides, the function of personal financial planning is to plan for future household or family financial needs efficiently that exist since humans have choices over their resources (Husniyah \& Mohd. Amin, 2013). Personal financial planning is an integrated long-term financial plan execution. It comprises of a few components like planning car purchases, house purchases, children's education, credit applications, protection from financial risks, property distribution, retirement needs and tax reduction.

\section{Marriage expenditures}

According to SYH Noorul Madihah (2017), marriage expenditures have to be managed as best as it can by individuals who want to get married. Expenditures in marriage according to Syariah must be for beneficial matters, following priorities, spending moderately and according to financial abilities, to ease expenditure affairs and cooperation in managing expenditures. Also, according to her, the existence of various wedding traditions that have been long practiced by the Malay community such as "majlis merisik" (surveying), dowry gifting to the bride's family and dowries exchange in an engagement ceremony as well as wedding have contributed to rising marriage expenditures nowadays. On the other hand, according to Khairuddin and Fauzi (2016), the current weddings of the Malay community are different from the traditional Malay community. Many of the weddings nowadays prioritise unnecessary matters like variations of commodities and wedding services that directly lead to wastage and excessive acts. The study said, regarding the theme and concept of a wedding, wedding packages, dowries, photographer packages and dream creations through the medium of new cultures.

\section{Financialsources}

According to Josephine T. et al. (2008), financial sources include salary, interest on bank account, rental income, gift, inheritance, bonus, commission and unemployment compensation. While SYH Noorul Madihah (2017) states that financial sources comprise of savings, contributions, borrowings and specific savings.

\section{a. Savings}

Savings are excess income that is not spent on current expenditures (Anon, 2010; Nurul Fardini et al., 2010). Savings are important because individuals do not know what will happen in the future. Money should be saved to pay for unexpected events or emergencies. Without savings, unexpected events can be a big financial burden. According to Yasmin and Anuar (2017), financial knowledge has a significant relationship with saving rates. Individuals with high financial levels will have fixed savings. This is because they have knowledge in managing their finance. According to SYH Noorul Madihah (2017), cash saving is a saving that is made by future brides and grooms. Savings can be done by making financial budgets to achieve a goal. For couples who want to get married, savings are made by saving up money received from working. There are also couples who do not have any savings and they start to save up after making the decision to get married.

\section{b. Contributions}

Contributions can be divided into many forms like money, time, goods and services that are given as help or support (Yuangao et al. 2019). In general, big contributions from the public can help the poor and needy in the whole world and these contributions can create trust, prosperity, education movements for children, development of religious understanding and other welfare activities to increase living standards (Kashif \& Ernest C. D. R., 2015). The behaviour of contributors to contribute large amounts of money depends on the cultural system, religion and several personal factors (Sampath \& Walter H. H., 2008). 


\section{c. Loans}

According to Daniel (2018), borrowings are divided into two, which are secured loans and unsecured loans. Secured loans are assets functioning as collateral. If debtors do not pay the borrowed money, creditors will take over the secured asset. While unsecured loans are loans given to individuals that are not guaranteed on an asset. For example, personal loans, credit cards, and student loans. From a customer's perspective, personal loans that are easy to be obtained, installment payments, without cash guarantee and relaxed terms and conditions, are the main things for borrowing customers (Shafinar et al., 2013). Loans can be made through family members, banking or credit institutions and pawn centres (SYH Noorul Madihah, 2017).

\section{d. Special Funds}

Specific savings from a local community is a cooperation method among the local community in collecting funds to support a part of wedding expenditure costs. There are also savings that are not used for banquets but are used to support other elements including gifts for guests and banquet equipment (SYH Noorul Madihah, 2017). For example, in Pakistan, Community-Based Savings Group (CBSG) was established to help in giving easy loans to mothers who will bear the costs of giving birth (Babar et al., 2017). Thus, this study uses the definition of specific savings as community cooperation in collecting expenses to ease the needy communities' affairs.

\section{Method}

This study uses a quantitative approach. The study population is the millennial generation aged 18 to 40 and was attending the premarital course at Medan Mara, Kuala Lumpur. Purposive sampling was used in this study because target respondents have to satisfy the following characteristics; aged 18 to 40, not married, Muslim and attending the premarital course. The result, 85 millennial generation people became respondents. Based on Cohen (1992) in Chua (2006), a sample size of 85 will suffice for this study. Questionnaires were used as the data collection instrument. There were four sections in the questionnaire instrument, which are Section A,B, C and D. Section A contained the background information of respondents. Section B contained marriage savings information. Section C contained marriage expenses information. Section $\mathrm{D}$ on the other hand contained information on financial sources obtained to celebrate a wedding. A descriptive data analysis was used to explain the study results.

\section{Results and Discussions}

\section{Respondents'Profile}

Table 1 shows the respondents' profile. Study results show that there are more male respondents (54.1\%) compared to female (45.9\%). Most of the respondents are between the age of 26 to 30 years old $(45.9 \%)$, followed by respondents less than 26 years old (42.4\%) and aged 36 to 40 (4\%). The majority of respondents have their education level at the secondary school level, which is as much as 35.3 percent. While a small portion of respondents have their education level at did not go to school, primary school and Master/PHD, where each recorded 1.2 percent of the respondents. For the work element, the majority of the respondents are working (94\%) and the rest is not working (6\%). Most respondents have a monthly income between RM1000 and RM2999 (62.4\%), followed by income RM3000 to RM4999 (16.5\%) and only 2.4 percent of the respondents have an income of RM9000 and above. The majority of respondents originate from Kuala Lumpur (44.7\%), followed by respondents who originate from Selangor (31.8\%) and the rest originating from Melaka, Kedah, Pahang, Perlis and Terengganu with each recording 1.2 percent. 
DOI: https://doi.org/10.47405/mjssh.v6i1.607

Table 1: Respondents' Profile

\begin{tabular}{|c|c|c|c|c|c|}
\hline Respondents' Profile & Freq. & $\%$ & Respondents' Profile & Freq. & $\%$ \\
\hline Gender: & & & Education Level: & & \\
\hline Male & 46 & 54.1 & Does not go to school & 1 & 1.2 \\
\hline Female & 39 & 45.9 & Primary School & 1 & 1.2 \\
\hline Age: & & & Secondary School & 30 & 35.3 \\
\hline$\leq 25$ & 36 & 42.4 & Certification/Diploma & 29 & 34.1 \\
\hline $26-30$ & 39 & 45.9 & First Degree & 23 & 27.1 \\
\hline $31-35$ & 7 & 8.2 & Master/PHD & 1 & 1.2 \\
\hline $36-40$ & 3 & 3.5 & Originate: & & \\
\hline Occupation: & & & Kuala Lumpur & 38 & 44.7 \\
\hline Unemployed & 5 & 5.9 & Selangor & 27 & 31.8 \\
\hline Employed & 80 & 94.1 & Melaka & 1 & 1.2 \\
\hline Monthly Income: & & & Johor & 4 & 4.7 \\
\hline$<\mathrm{RM} 1000$ & 4 & 4.7 & Pinang & 5 & 5.9 \\
\hline RM1000-RM2999 & 53 & 62.4 & Kedah & 1 & 1.2 \\
\hline RM3000-RM4999 & 14 & 16.5 & Kelantan & 2 & 2.4 \\
\hline RM5000-RM6999 & 4 & 4.7 & Pahang & 1 & 1.2 \\
\hline RM7000-RM8999 & 3 & 3.5 & Sabah & 4 & 4.7 \\
\hline RM9000 and above & 2 & 2.4 & Perlis & 1 & 1.2 \\
\hline No Income & 5 & 5.9 & Terengganu & 1 & 1.2 \\
\hline
\end{tabular}

\section{Marriage Savings}

This section explains specific savings for getting married, reasons for having specific savings to get married, reasons for not having specific savings to get married, and views related to specific marriage savings.

\section{a. Specific savings for getting married}

Figure 1 shows the respondents percentage who make specific savings to get married. A big portion of respondents has specific savings for getting married (96\%). Among the 96 percent of respondents, the majority is male (54.49\%) compared to females (41.51\%). While respondents who do not have specific savings for getting married are made up of 2.55 percent of females and 1.45 percent of males.

Figure 1: Specific savings for getting married

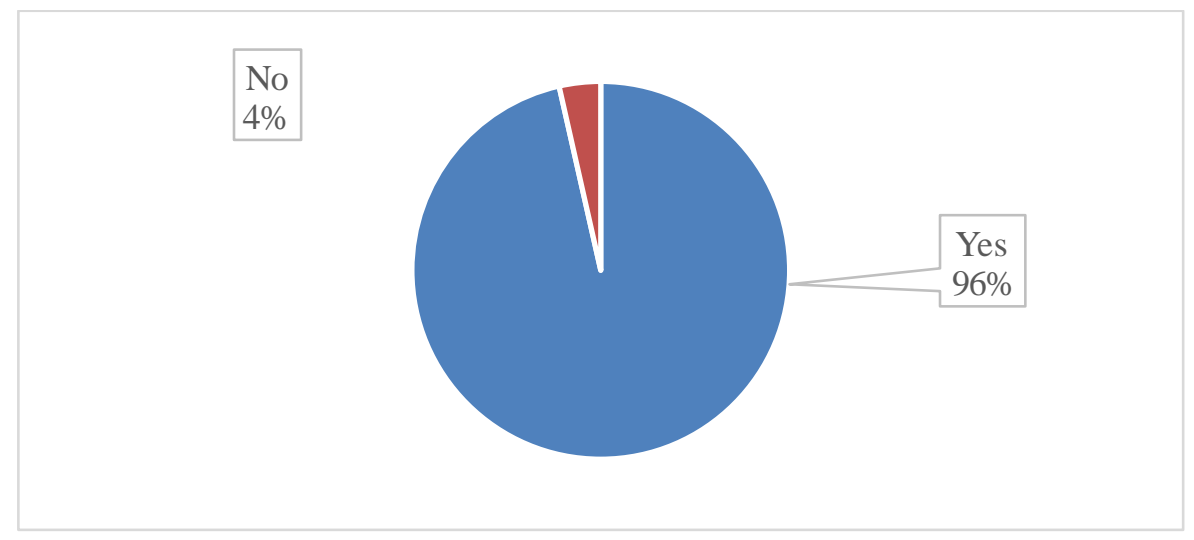

b. Reasons for having specific savings for getting married

Table 2 shows the reasons that are agreed by respondents related to specific savings for getting married. Most respondents agree that specific savings for getting married are their responsibility $(69.4 \%)$. Followed by the reason 'I feel that specific marriage savings are to lighten the burden of my parents' 
(58.8\%). Other than that, as many as 55.3 percent of respondents have specific savings to get married because they are from moderate families. Respondents who have specific savings for getting married are also for meeting the needs of high marriage expenses (41.2\%) and want to help themselves to achieve their dream marriage (40\%).

Table 2: Reasons for having specific savings for getting married

\begin{tabular}{lr}
\hline Reason for having savings for getting married & Freq. (\%) \\
\hline I feel that specific savings for marriage are my responsibility. & $59(69.4)$ \\
Specific marriage savings are to lighten the burden of my parents. & $50(58.8)$ \\
I am from a moderate family. & $47(55.3)$ \\
Specific savings for marriage are to meet the needs of high marriage expenses. & $35(41.2)$ \\
$\begin{array}{l}\text { Specific savings for marriage are to help individuals to achieve their wedding } \\
\text { dream. }\end{array}$ & $34(40)$ \\
\hline
\end{tabular}

c. Reasons for not having specific savings for getting married

Table 3 shows the reasons for respondents who do not have specific savings for getting married. A big portion of respondents agree with the reason 'debt burdens like monthly vehicle payments, insurance and others exceed income' is their reason for not having specific savings for getting married (7.1\%). Next, respondents do not have specific savings for getting married because they 'make loans to get married' and 'marriage expenditures are completely borne by parents' each with a percentage of 3.5 percent of the respondents. For 'expenditures are completely borne by parents' (3.5\%), respondents involved are women. The same goes for those who do not have specific savings for getting married because 'not working and have no income' $(1 \%)$.

Table 3: Reasons for not having savings for getting married

\begin{tabular}{lr}
\hline Reason for not having savings for getting married & Freq. (\%) \\
\hline Not working; Have no income. & $1(1.2)$ \\
Make loans to get married. & $3(3.5)$ \\
Marriage expenditures are completely borne by parents. & $3(3.5)$ \\
Have financial savings for the future but not specific for getting married. & $4(4.7)$ \\
Debt burdens like monthly vehicle payments, insurance and others exceed & $6(7.1)$ \\
income. & \\
\hline
\end{tabular}

Besides, respondents' reason for not having specific savings for getting married is because the respondents have financial savings for the future but not specific for getting married (4.7\%). Usually, for these respondents, they do not plan their finances specifically for a particular matter like getting married. There are savings made to face days where emergencies happen. Savings are important because an individual does not know what will happen in the future (Anon, 2010). Money must be saved to pay for unexpected events or emergencies.

d. Views related to specific marriage savings

Table 4 shows respondents' views related to specific marriage savings. All respondents agree with 'specific savings for getting married allow individuals to plan their expenses according to their capability' $(100 \%)$. While the least number of respondents agreed to the statement 'specific savings are hard to make because money is also needed to pay other commitments like car loans, study loans, credit cards, insurance and others' (58.5\%). This matter explains that with existing financial commitments, it is hard for the respondents to make specific savings to get married. The majority of respondents who agree with this statement have an income of between RM1000 to RM2999, which is as many as 31 respondents from 50 respondents.

Table 4: Views related to specific marriage savings 


\begin{tabular}{lrr}
\hline Views related to specific marriage savings & $\begin{array}{r}\text { Yes } \\
\text { Freq. } \\
(\mathbf{\%})\end{array}$ & $\begin{array}{r}\text { Freq. (\%) } \\
\text { No }\end{array}$ \\
\hline $\begin{array}{l}\text { Specific savings for marriage allow individuals to plan expenditures } \\
\text { according to their capability. }\end{array}$ & $85(100)$ & $0(0.0)$ \\
$\begin{array}{l}\text { Specific savings for marriage prevent couples from being indebted. } \\
\text { Specific savings for marriage allow couples to realise their marriage } \\
\text { dreams. }\end{array}$ & $84(98.8)$ & $1(1.2)$ \\
$\begin{array}{l}\text { Specific savings for marriage can lessen individuals' financial burden to } \\
\text { celebrate their wedding. }\end{array}$ & $82(96.5)$ & $3(3.5)$ \\
$\begin{array}{l}\text { Specific savings for marriage are hard to make because money is also } \\
\text { needed to pay other commitments (like car loans, study loans, credit } \\
\text { cards, insurance and many more.) }\end{array}$ & $50(58.8)$ & $35(41.2)$ \\
\hline
\end{tabular}

In conclusion, most respondents agree with the statements in Table 4. Although there are respondents who do not have specific savings for getting married, they have views and knowledge related to specific marriage savings. This finding is different from the finding in Yasmin and Anuar's (2017) study, where financial knowledge has a significant relationship with saving rates. Individuals with a high financial level will have fixed savings.

\section{Wedding Expenses}

This section will explain about service choices for weddings, marriage expenses estimates, and the overall wedding expenses estimates.

a. Service choices for weddings

Table 5 shows the services that become the choices of respondents in the preparation of a wedding. The choices are arranged based on priority, that is 1 being the foremost main. Respondents said that catering packages are the foremost main service for their wedding $(75.3 \%)$. Followed by a wedding card service $(72.9 \%)$. Next, the minimum number is for candy corner service that is as many as only 8.2 percent of respondents who use this service at their wedding. They consist of 5 males and 2 females. For the service of body beauty treatment, as many as 18.8 percent of respondents want to use this service. Among the 18.8 percent of respondents, 10.58 percent are females, while the rest are males $(8.22 \%)$.

Table 5: Services that become choices in the preparation of a wedding

\begin{tabular}{clrr}
\hline Service Wedding & $\begin{array}{r}\text { Yes } \\
\text { Freq. }(\boldsymbol{\%})\end{array}$ & $\begin{array}{r}\text { No } \\
\text { Freq. }(\mathbf{\%})\end{array}$ \\
\hline 1. & Catering Packages & $64(75.3)$ & $21(24.7)$ \\
2. & Wedding Card & $62(72.9)$ & $23(27.1)$ \\
3. & Outfit and Dais Packages & $60(70.6)$ & $25(29.4)$ \\
4. & Photography Pre-Wedding, Indoor and Outdoor & $51(60.0)$ & $34(40.0)$ \\
5. & Grooming Package & $48(56.5)$ & $37(43.5)$ \\
6. & Venue & $48(56.5)$ & $37(43.5)$ \\
7. & Door Gift & $45(52.9)$ & $40(47.1)$ \\
8. & Photo Booth & $20(23.5)$ & $65(76.5)$ \\
9. & Body Beauty Treatment & $16(18.8)$ & $69(81.2)$ \\
10. & Entertainment & $14(16.5)$ & $71(83.5)$ \\
11. & Candy Corner & $7(8.2)$ & $78(91.8)$ \\
\hline
\end{tabular}

b. Wedding expenses estimates

Table 6 shows the respondents' wedding expenses estimates. Based on the table, the maximum amount of respondents' wedding expenses estimate is for catering packages with a maximum value of 
RM33,500. The average value for catering packages is RM7,091.76. This matter is in line with SYH Noorul Madihah (2017) who stated that expenditure for the banquet and equipment element involves thousands of Ringgit.

The second highest expense is for dowries. The average amount for this element is RM6,770.59 with the maximum value RM25,000. In this expense estimate, if looking at education background, there was a respondent that has a Masters/PHD education level who put an expense estimate of RM10,000 while another respondent who has a first degree education level, put the dowry expense estimate at RM25,000.

In addition, most respondents put the value of dowry expense estimate at RM10,000 with a record of 30 respondents from 59 respondents who answered this expense estimate. In a past study by Raihanah et al. (2009), dowry rates among the northern Malaysian peninsula community found that majority of respondents stated the most reasonable rates for dowries are between RM5,000 to RM8,000. This matter shows that dowry is an important element in marriage expenses nowadays.

Table 6: Wedding expenses estimates

\begin{tabular}{lrr}
\hline Wedding expenses & Mean & Standard Deviation \\
\hline Dowry (Hantaran) & 6770.59 & 6035.881 \\
Dowry (Mas Kahwin) & 582.56 & 1330.551 \\
Wedding Card & 207.18 & 248.033 \\
Grooming Package & 508.24 & 1089.775 \\
Body Beauty Treatment & 130.59 & 366.864 \\
Catering Packages & 7091.76 & 8428.921 \\
Outfit And Dais Packages & 1445.27 & 1903.185 \\
Door Gift & 635.53 & 774.544 \\
Photography Pre-Wedding, Indoor and Outdoor & 960.00 & 1218.405 \\
Photo Booth & 115.29 & 283.686 \\
Candy Corner & 79.76 & 230.620 \\
Entertainment & 218.24 & 765.508 \\
Venue & 1734.71 & 4541.004 \\
\hline
\end{tabular}

For the aspect of wedding venue expense estimate, the average amount was RM1,734.71 with a maximum value of RM30,000. According to SYH Noorul Madihah (2017), individuals who live outside the city spend money on the provision of wedding venues. The expense amounts to RM4,000 for a venue like a hall. There are some who spend money to celebrate their wedding in a hotel hall which costs as much as RM48 per person.

Next, the lowest expense estimate in a wedding is the candy corner element with an average estimate value of RM115.29 and a maximum amount of RM1,000. Then, outfit and dais packages which recorded an average value of RM1,445.27 with a maximum amount of RM10,000. A study by Khairuddin and Fauzi (2016) said that expensive wedding packages are not an obstacle for respondents to fulfill their desire because they have prepared sufficient allocation so that their desires are met. Then, with a maximum value of RM10,000 for outfit and dais packages, this shows that respondents have sufficient allocation to fulfill their wedding dreams.

Overall, wedding expenses estimates nowadays are high, moreover, there are various services provided for future brides and grooms. Although weddings nowadays are held to fulfill religious and custom demands, at the same time they are also held to fulfill their dream weddings through wedding services provided by the wedding industry (Khairuddin \& Fauzi, 2016).

c. Overall expense estimates

Figure 2 shows overall expense estimates by 85 involved respondents. The highest overall expense estimate is between RM10,000 and RM15,999 (28.3\%). Males recorded as many as 14 people and 
DOI: https://doi.org/10.47405/mjssh.v6i1.607

females recorded as many as 10 people (Refer to Table 7). From the income aspect, 19 out of 24 respondents receive monthly work income of between RM1,000 and RM2,999 (Refer Table 8).

Figure 2: Overall expense estimates

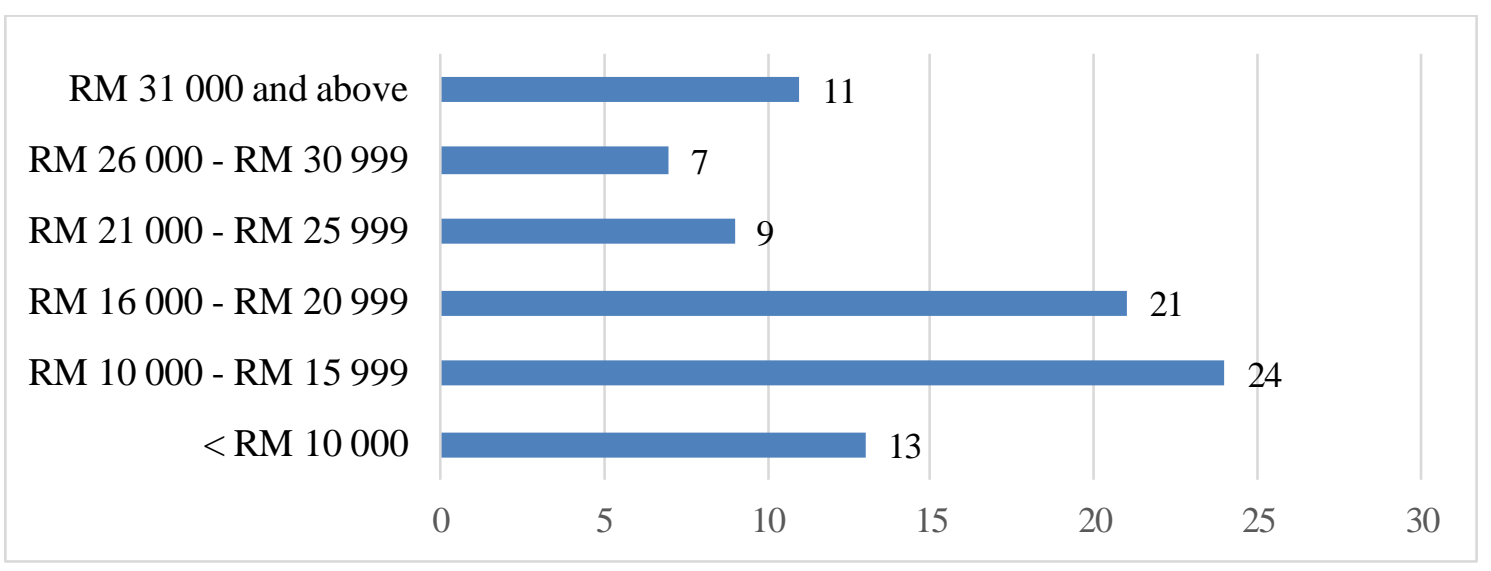

Next, followed by an overall expense estimate of RM16,000 to RM20,999 (24.7\%). They consist of 9 males and 12 females (Table 7). In majority it recorded as many as 14 respondents with income between RM1,000 and RM2,999 (Refer Table 8). However, there were also two respondents each with income between RM7,000 and RM8,999; RM9,000 and above. The minimum overall wedding expense estimate is between RM26,000 and RM30,999 (8.2\%). Involved respondents are those with income between RM1,000 and RM6,999 (Refer to Table 8). Other than that, an overall expense estimate of RM10,000 and below is as many as 15.3 percent of respondents. The majority are males, as many as 7 and 6 are females.

Table 7: Overall expense and gender

\begin{tabular}{lrrr}
\hline Expenses & $\begin{array}{r}\text { Male } \\
\text { Freq. }(\%)\end{array}$ & $\begin{array}{r}\text { Female } \\
\text { Freq. }(\%)\end{array}$ & $\begin{array}{r}\text { Overall } \\
\text { Freq. }(\%)\end{array}$ \\
\hline <RM10000 & $7(15.2)$ & $6(15.4)$ & $13(15.3)$ \\
RM10000 to RM15999 & $14(30.4)$ & $10(25.6)$ & $24(28.3)$ \\
RM16000 to RM20999 & $9(19.6)$ & $12(30.8)$ & $21(24.7)$ \\
RM21000 to RM25999 & $6(13.0)$ & $3(7.7)$ & $9(10.6)$ \\
RM26000 to RM30999 & $3(6.5)$ & $4(10.3)$ & $7(8.2)$ \\
RM31000 and above & $7(15.2)$ & $4(10.3)$ & $11(12.9)$ \\
\hline Total & 46 & 39 & $85(100)$ \\
\hline
\end{tabular}

Meanwhile, there are 12.9 percent of the respondents who their overall expense estimate is RM31,000 and above. They consist of 7 males and 4 females (Table 7). In addition, they are in majority with incomes of between RM3,000 to RM4,999 (Table 8). However, with this high expense estimate, there are also respondents with incomes between RM1,000 to RM2,999 and without income (Table 8). Then, followed by overall expense estimates of RM21,000 to RM25,999 (10.6\%). Among them, most of them have incomes of RM1,000 to RM2,999. However, there are also 4 respondents with incomes of RM3,000 to RM4,999 (Refer to Table 8). They consist of 6 males and 3 females (Refer to Table 7). Overall, the expense nowadays is high, to the point that there are wedding expense estimates that reach RM31,000 and above.

Table 8: Overall expense and income

\begin{tabular}{|c|c|c|c|c|c|c|c|c|}
\hline \multirow[t]{2}{*}{ Expenses } & \multicolumn{7}{|c|}{ Income } & \multirow[t]{2}{*}{ Total } \\
\hline & 1 & 2 & 3 & 4 & 5 & 6 & 7 & \\
\hline$<\mathrm{RM} 10000$ & 3 & 8 & 1 & 1 & 0 & 0 & 0 & 13 \\
\hline
\end{tabular}



DOI: https://doi.org/10.47405/mjssh.v6i1.607

\begin{tabular}{lrrrrrrrr} 
RM10000 to RM15999 & 1 & 19 & 1 & 1 & 0 & 0 & 2 & 24 \\
RM16000 to RM20999 & 0 & 14 & 3 & 0 & 1 & 1 & 2 & 21 \\
RM21000 to RM25999 & 0 & 5 & 4 & 0 & 0 & 0 & 0 & 9 \\
RM26000 to RM30999 & 0 & 5 & 1 & 1 & 0 & 0 & 0 & 7 \\
RM31000 and above & 0 & 2 & 4 & 1 & 2 & 1 & 1 & 11 \\
\hline Total & 4 & 53 & 14 & 4 & 3 & 2 & 5 & 85 \\
\hline
\end{tabular}

\section{Marriage Financial Sources}

Table 9 shows marriage financial sources received by respondents to make preparations for their marriage. Most respondents state that their marriage financial source is from their own savings or funds. Of the total, 45 are males and 35 are females. This shows that males save more than females because according to the old and current Malay customs, dowry is given by the male party to the female party. It is clearly proven that males save more money for marriage than females. This matter is in line with SYH Noorul Madihah (2017) who states that the value of dowry placed by the bride's family is also increasing nowadays. Then, it is no surprise when there are more males compared to females in personal fund savings.

Meanwhile, a record of 14.1 percent of respondents have their financial source from bank loans. The majority consist of males with a total of 8 respondents. Although males have more savings, this matter is still relatable because they still need other financial sources like bank loans. In addition, those who made bank loans have a Certificate/Diploma, Secondary School and First-Degree education levels. There are also respondents who their financial source is completely borne by parents $(4.7 \%)$ and all these respondents are females. This finding is similar to SYH Noorul Madihah (2017) especially for those who have daughters who are still studying and not yet working. These involved respondents have Secondary School and Certificate/Diploma education levels.

Table 9: Marriage financial sources

\begin{tabular}{lrr}
\hline Financial Sources & $\begin{array}{r}\text { Yes } \\
\text { Freq. (\%) }\end{array}$ & $\begin{array}{r}\text { No } \\
\text { Freq. (\%) }\end{array}$ \\
\hline Own Savings Or Funds & $80(94.1)$ & $5(5.9)$ \\
Cash Contributions from Parents & $38(44.7)$ & $47(55.3)$ \\
Cash Contributions from Brothers, Sisters and Friends & $25(29.4)$ & $60(70.6)$ \\
Cash Contributions from Other Family Members & $19(22.4)$ & $66(77.6)$ \\
Bank Loan & $12(14.1)$ & $73(85.9)$ \\
Loans from Family and Friends & $5(5.9)$ & $80(94.1)$ \\
Completely Borne by Parents & $4(4.7)$ & $81(95.3)$ \\
Fund Collection from The Local Community & $3(3.5)$ & $82(96.5)$ \\
Financial Source from Pawning & $1(1.2)$ & $84(98.8)$ \\
\hline
\end{tabular}

From the aspect of cash contributions from parents, cash contributions from brothers, sisters and friends and cash contributions from other family members each recorded (44.7\%), (29.4\%) and (22.4\%) respondents. SYH Noorul Madihah (2017) also found that many parents spend money to settle a few elements, especially banquets. Therefore, evidently almost half of the total respondents will use the financial source of cash contributions from parents. Other than that, there was one respondent with a financial source from pawning (1.2\%). The respondent is male. Have a Secondary School education level and income of between RM3,000 and RM4,999. Furthermore, the overall expense estimate of this respondent was as much as RM21,000 to RM25,999. This can be seen that high expenses drive the respondent to opt for a pawn loan.

Next, for respondents who will make loans from family and friends as their financial source the amount is 5.9 percent of respondents. The majority from the percentage have incomes of between RM1,000 to RM2,999, followed by incomes between RM3000 to RM4999 and there are also those 
with no income. Also not left out, financial source from fund collection from the local community (3.5\%). For this fund collection, the incomes of involved respondents are between RM1,000 and RM4,999. Overall, although the majority of respondents have marriage savings, financial sources from other parties are also needed no matter in the form of contributions or loans. This matter has been explained, these loans and contributions are from cash loans, pawn loans, receiving contributions from parents, friends, and family members as well as fund collection from the community.

\section{Conclusion}

Study results show a higher number of male respondents who have savings to get married compared to females. This is because expenses to get married according to traditional Malay customs, dowry giving is made by males to females. This explains why males have to save more than females. Although traditional customs are being practiced, there is a difference between current services which is the choice of various modern services provided like candy corner, prewedding photo-shoot, indoor and outdoor as well as other packages that become the desire of millennial to achieve their marriage dreams. Other than that, this study also shows a few types of financial sources that will be used by respondents to celebrate their wedding. Although respondents have their own savings, there are among them who receive contributions from other parties, for example, family members' contributions, loans from family, pawn loans and fund collection from the local community. Fundamentally, financial planning is important in every life. Therefore, this study implication suggests the millennial generation to be smarter in planning their personal finances, especially planning savings more effectively and expenditures for marriage that follow their capability so that they will not fall into debt burdens and financial crises in the future.

\section{Acknowledgment}

Appreciation goes to Ministry of High Education for research funding through Fundamental Research Grant Scheme FRGS/1/2019/SS08/UKM/02/1.

\section{References}

Anon. (2010). Family economics \& financial education. https://financeintheclassroom.org/ downloads/WhatSavingswhyimportant.pdf

Chua Lee Chuan. (2006). Sample size estimation using Krejcie and Morgan and Cohen Statistical Power Analysis: A Comparison. Jurnal Penyelidikan IPBL, 7, 82.

Chen-Chen Yong, Siew-Yong Yew \& Chu-Kok Wee. (2018). Financial knowledge, attitude and behaviour of young working adults in Malaysia. Institutions and Economies, 10(4), 21- 48.

Copur, Z. \& Eker, I. (2014). The relationship between financial issues and marital. International Journal of Art and Sciences, 7(05), 683-69.

Daniel Harari. (2018). Household debt: Statistics and impact on economy. House of Commons Library.

Dwiyun Evi Yolanda, Isti Mulyani \& M. Januar Ibnu Adham. (2017). Pengaruh generasi muda millenial terhadap karakter interaksi sosial di masyarakat. https://www.academia.edu/ 35489302/pengaruh_generasi_muda_millenial_terhadap_karakter_interaksi. 10 Februari 2020.

Garman, E.T. \& Forgue, R.E. (2006). Personal Finance. 8th Edition. New York: Houghton Mifflin Company.

Husniyah A.R. \& Mohd Amin. (2013). Public worker's personal financial planning process and involvement in comprehensive financial planning. https://www.researchgate.net/ publication/289774725_Public_worker's_personal_financial_planning_process_and_involveme nt_in_comprehensive_financial_planning

Josephine, T., Nayda, I. T., Vervill, M. \& Michael, G. (2008). Money and marriage: A spending plan. https://rvs.umn.edu/Uploads/EducationalMaterials/406ddd01-2442-48ed-8213-

b1e2ad5d6358.pdf 
Kapoor, D. \& Hughes. (2012). Personal Finance. 4th Edition. Mc Graw-Hill Companies.

Khairuddin \& Fauzi. (2016). Impian dan realiti majlis perkahwinan orang Melayu Masakini: Kajian kes di pinggir Bandar Kuala Lumpur. Malaysian Journal of Society and Space, 12(7), 1-12.

Koon Foo Yu \& Nurazrin Jupri. (2015). Factors that lead to financial distress of Generation Y in Malaysia. International Journal of Accounting \& Business Management, 3(2).

Liezel Alsemgeest \& Chrizaan Grobbelaar. (2015). Spouse' views of gender roles: Financial management in marriage. Journal of Economic and Financial Sciences, 8(3), 843-860.

Malaysian Department of Insolvency. (2020). Statistik Kebankrapan 2019. http://www.mdi.gov.my/images/documents/Statistics/Bankrupcy/StatistikKebankrapandisember 2019.pdf. 19 Februari 2020.

Markus, K. (2017). Comparing Generation X and Generation Y on their preferred emotional leadership style. Journal of Applied Leadership and Management, 5, 62-75.

Kashif, M. \& Ernest C. D. R. (2015). Money donations intentions among muslim donors: An extendended theory of Planned Behavior Model. International Journal of Nonprofit and Voluntary Sector Marketing, 1-14.

Irawan, Yossie Rossanty, dan Muhammad Dharma Tuah Putra Nasution. (2018). Financial Literacy for Family Welfare Within Financial Planning. The 4th International Conference on Management Sciences.

Md Abdul Jalil, Dzuljastri Abdul Razak \& SM Ferdous Azam. (2013). Exploring factors influencing financial planning after retirement: Structural Equation Modeling Approach. American Journal of Applied Sciences, 10(3), 270-279.

Noraihan, Hasmida \& Syaiful. (2013). Hubungan antara amalan pengurusan kewangan pelajar dam kursus PA305: Pengurusan Kewangan Peribadi-Satu Kajian Kes di Politeknik Tuanku Sultanah Bahiyah. Technical and Education Colloquium (TEC) PTSB, 25-31.

Normaizatul Akma Saidi, Nurul Ayuni Khairuddin, Nurul Azlina Abu Samat, Nurul Azween A. Rahman \& Nurul Fadzlina Abdul Jalil. (2016). Determinants of financial problems among adults. International Journal of Accounting, Finance and Business, 1(1) September, 18-23.

Norsyahidah Norazam \& Norasmah Othman. (2017). Kualiti pendidikan pengurusan kewangan dengan tahap literasi kewangan. Journal of Global Business and Social Entrepreneurship (GBSE), 1(1), 183-193.

Nurul Fardini Zakaria, Laily Palm dan Husniyah Abdul Rahim. (2010). Perbadingan Lestari Kewangan Siswa Berasaskan Gender. Jurnal Pengguna Malaysia, 15, 50-64.

Raihanah Azahari, Khairun Najmi Saripudin dan Raihana Abd Wahab. (2009). Hubungan di antara Faktor Demografi dengan Penentuan Kadar Hantaran:Kajian di Perlis, Kedah, Pulau Pinang dan Perak. Jurnal Fiqh, 6, 107-124.

Rumaya Juhari, Syah Qurratu Ani Sahrani dan Khairul Anwar Mastor. (2014). Personality Traits and Marital Quality Among Muslims Newly Weds in Selangor, Malaysia. Proceedings of the Australian Academy of Business and Social Sciences Conference 2014 https://pdfs. semanticscholar.org/8660/effd1690c341650ec32acde691af0ff1f97d.pdf

Sampath Kumar Ranganathan \& Walter H. H. (2018). Determinants of Charitable Donation Intentions: A Structural Equation Model. International Journal of Nonprofit and Voluntary Sector Marketing, 13(1), 1-11.

Shafinar Ismail, Rozana Othman, Siti Noor Hidayuu Kamalrulzaman, Arnida Jahya, Nur Hafidzah Idris, Siti Zaitun dan Farid Izren. (2013). Determinants of personal loans borrowing: An Empirical Study. https://www.researchgate.net/publication/260985991_Determinants_of Personal_Loans_Borrowing_An_Empirical_Study

Stanimir, A. (2015). Generation Y characteristics of attitudes on labour market. Mediterranean Journal of Social Sciences, 6(2), 23-27.

Syahira Sa'aban, Noraisah Ismail \& Mohd Fitri Mansor. (2013). A study on Generation Y behavior at workplace. International Conference on Business Innovation, Entrepreneurship and Engineering 2013.

SYH Noorul Madihah. (2017). Gelagat perbelanjaan perkahwinan masyarakat melayu muslim menurut perspektif syariah. Tesis Dr. Fal, Akademi Pengajian Islam, Universiti Malaya, Kuala Lumpur.

Thulasimani Munohsamy. (2015). Personal financial management. Institut Teknologi Brunei. https://www.researchgate.net/publication/279198054 
DOI: https://doi.org/10.47405/mjssh.v6i1.607

Willis, L. E. (2008). Evidence and ideology in assessing the effectiveness of financial literacy education. Scholarship at Penn Law. Paper 206. Retrieved online at http://lsr.nellco.org/upenn_ wps/206

Yasmin \& Anuar. (2017). Tahap literasi kewangan di kalangan mahasiswa. https://www.researchgate.net/publication/321049902_TAHAP_LITERASI_KEWANGAN_DI_ KALANGAN_MAHASISWA

Yuangao Chen, Ruyi Dai, Jianrong Yao \& Yixiao Li. (2019). Donate time or money? The determinants od donation intention in online crowdfunding. 12 February 2020. https://www.researchgate.net/publication/335044170_Donate_Time_or_Money_The_Determina nts_of_Donation_Intention_in_Online_Crowdfunding 